\title{
Paleo-environmental Reconstruction of Oligocene to Early Miocene Sediments of Greater UghelliDepobelt, Niger Delta Basin
}

\author{
LUCAS, FA; FREGENE, TJ \\ *Department of Geology, University of Benin, Benin City, Nigeria \\ Email:drfalucas@gmail.com, talktobabat4us@yahoo.com
}

\begin{abstract}
Paleoenvironmental study of Oligocene to Early Miocene sediments of Greater UghelliDepobelt Niger Delta Basin were carried outusing foraminiferal micropaleontology as geologic tools.Fifty (50) ditch cutting samples ranging from $20 \mathrm{ft} .-11,820 \mathrm{ft}(6.09 \mathrm{~m}-3603.7 \mathrm{~m})$ was used with the aim of establishing thepaleo-environment of the well. A total of twenty six (26) foraminiferal species were recorded, most of the species recorded are calcareous and arenaceous benthic foraminiferal species while planktonic foraminiferal species are generally scarce in the well. The non-recovery of planktonic and the general poor recovery of foraminiferal species might be due to environmental factor.The foraminiferal abundances revealed two varying depositional environment which are Continental to Marginal Marine and Proximal to distal Inner Neritic environment. These deductions were based primarily on benthic foraminiferal assemblage, their abundance and diversity. The presence or absence of planktonic foraminifera also helped in deciphering open ocean environments.The Continental to Marginal Marine setting range from 1640ft to $11,100 \mathrm{ft}$ due to non-recovery to rare foraminiferal species recorded within this interval while the Proximal to Distal Inner Neritic ranges from $11,160 \mathrm{ft}$ to $11,760 \mathrm{ft}$ with the presence of few foraminiferal species consisting of rare benthic foraminiferal species and scarcity of planktonics foraminiferal species indicating deposition in a shallow water, suggesting sediments deposition is fluctuating between proximal to distal Inner Neritic.
\end{abstract}

\section{DOI: https://dx.doi.org/10.4314/jasem.v22i1.18}

Copyright: Copyright (9) 2017 Lacus and Fregene. This is an open access article distributed under the Creative Commons Attribution License (CCL), which permits unrestricted use, distribution, and reproduction in any medium, provided the original work is properly cited

Dates: Received 06 October 2017, received in revised form 22 November 2017, accepted 09 December 2017.

Keywords; foraminiferal; Proximal to Distal Inner Neritic;Paleoenvironment; Niger Delta Basin; Depobelt

The Niger Delta is the most significant hydrocarbon province on the West African continental margin. It lies mainly in the Gulf of Guinea to the southwest of the Benue - Trough and constitutes the most important Cenozoic deltaic construction in the south Atlantic. Because of its petroliferous nature, the economy of Nigeria depends largely on the oil and gas derived from it. The Cenozoic Niger Delta is situated at the intersection of the Benue Trough and the South Atlantic Ocean where a triple junction developed during the separation of South America and Africa in the Late Jurassic (Whiteman, 1982). Geologically it is found in the Tertiary period in the geologic column. The combination of source rock, lithologic types, structures and thermal history of the basin are favorable for the generation, accumulation and retention of hydrocarbons Whiteman, (1982); Stacher, (1995). The use of lithofacie and biostratigraphy as tools and components in evaluating sedimentary pile and basin analysis has become increasingly important in recent times as seen in works by Bolli, HM. and Saunders, JB (1985);Haq, BU (1987);Kennet, J and Srinivasan MS,(1983);Fadiya SL,( 1999);Chiaghanam, et al., (2013).
Biostratigraphy is an essential tool for dating rocks and identifying the biotic record through time and is necessary for establishing temporal correlation, reconstructing paleogeography, paleoenvironmental reconstruction as well as recognition of oil and gas deposits and intervals. It is essential to the petroleum industry as a tool for defining geologic constraints on prediction of exploration risk and modeling reservoir simulation. Allmon, (1993) stated that paleontology is still a necessary geologic tool because the geologic time scale is based on fossils, fossils are still the primary tool for dating sedimentary rocks and fossils records the history of life and environmental changes.

This study is aimed at establishing the paleoenvironment of sedimentary succession penetrated by the drill. The specific objective is to identify the foraminifera contents as well as establish the foraminifera diversity and abundance. The well is a well drilled to a total depth of $11,820 \mathrm{ft}$. It is located in the Greater UghelliDepobelt of Niger Delta basin defined by the following coordinates: Longitude $6^{0} \mathrm{E}$ and $7^{0} \mathrm{E}$ and Latitude $5^{\circ} \mathrm{N}$ and $6^{\circ} \mathrm{N}$ (Figure 1). 
Niger delta stratigraphy: The Tertiary Niger delta complex is divided into three formations, representing prograding depositional facies that are distinguished mostly on the basis of sand-shale ratios. They are the Akata, Agbada and Benin Formations. These formations have been reviewed as described in Short and Stauble, (1967) and summarized in a variety of papers Avbobvo, (1978); Doust and Omatola, (1990); Kulke, (1995) etc.

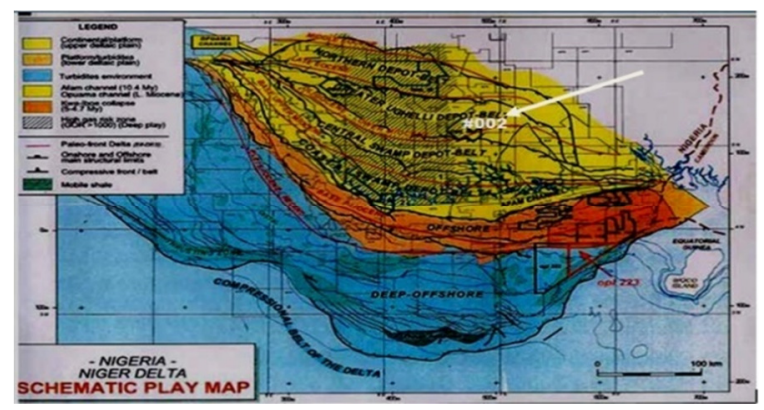

Fig. 1: Map showing Location of the Well Niger Delta Nwozor, et al.,(2013)

Benin Formation:This is the uppermost unit in the basin and predominantly (over 90\%) sandy with isolated clay/shale intercalations. The sands are coarse grained, granular, poorly sorted, subangular to well rounded. They are white or yellowish-brown and contain thin lignite streaks and wood fragments. The sediments are of continental to deltaic plain origin. The sands and sandstones may represent point bar deposits, channelfills and natural levees, whereas the shales may be interpreted as backswamp deposits or ox-bow fills. The Benin Formation is thicker in the central onshore part of the delta where it reaches about 2,000m Avbobvo, (1978) and thins outwards towards the delta margins. It ranges in age from Oligocene to Recent.

Agbada Formation: This unit comprises cyclic sequences of alternating sands (fluviatile, coastal, and fluviomarine) and marine shales. Two (2) distinct intervals are easily recognizable: an upper sandy unit with minor shale intercalations and a more marine lower unit in which the shaly sections become prominent. The sandstones and sands are very coarse to very fine grained, unconsolidated or slightly consolidated and poorly sorted. Lignite streaks are common. The shales are grey and dense at the base becoming markedly sandy and silty upward. The Agbada Formation is up to $4,000 \mathrm{~m}$ thick in the central part of the delta, thinning seaward and towards the delta margins. Known age ranges from Eocene to Recent.
Akata Formation:This is the basal unit of the Niger Delta complex. It consists of uniformly developed shales deposited in an open marine environment. There is the presence of some sand beds considered to be of continental slope, channel-fills and turbidites Weber and Daukoru, (1975). The formation is largely undercompacted (overpressured). The actual thickness is not known due to inability to penetrate the formation fully except on the basin flanks. The age span is Paleocene to Recent.

\section{MATERIALS AND METHOD}

Fifty (50) ditch cutting samples were selected and collected at different interval from depth of $20 \mathrm{ft}$. $(6.09 \mathrm{~m})$ to $11,820 \mathrm{ft}$. $(3603.7 \mathrm{~m})$ because of their shale facies content. The samples were utilized for foraminifera analyses. They were analyzed under the microscope for their foraminiferal content.

Foraminiferal Sample Preparation:The sample preparation was carried out following the international standards given below.

Materials: Sieves, distilled water, water jet: Procedure: Having observed all safety requirements, $20 \mathrm{gm}$ of each sample is weighed (using a Mettler PC 440 digital balance) into each sample bowl.

Depths on samples are correctly transferred to clean aluminium sample bowls. $30 \mathrm{ml}$ of kerosene is poured into sample while still hot to soak for two hours. Drain out kerosene and soak sample in water.20\% Hydrogen peroxide is then poured into the sample for about 10minutes. Each sample is then washed over a 63 microns sieve with water from a hand directed water jet. The residue collected from the sieve is replaced in the sample bowl and dried on the hot plate. The residue then sieved over 20 and 80 mesh sieves for the coarse and medium fractions while the finest residue in the receiver is treated as fine fraction. The coarse, medium and fine fractions are then stored in properly labeled sample phials for onward transfer to the pickers and analyzers.

\section{RESULT AND DISCUSSION}

Foraminiferal Abundance:Foraminiferal assemblage over the analyzed interval is generally poor with some barren intervals. A total of twenty six (26) foraminiferal species were recorded, most of the species recorded are calcareous and arenaceous benthic foraminiferal species. Planktic foraminiferal species are generally scarce in the well. The nonrecovery of planktic and the general poor recovery of foraminiferal species might be due to environmental factor. 
Species recorded include: Sproplectamminawrightii, Florilusatlanticus, Eponidescfeshira, Nonioncentrosulcatum,

Alveolophragmiumcrassum.A

Quinqueloculinarhodiensis,

foraminiferal distribution, abundance and diversity chart of the recovered Forms are presented table 1.

Table 1:Presentation of foraminifer's results

\begin{tabular}{|c|c|c|c|c|}
\hline $\mathbf{S} / \mathbf{N}$ & DEPTH(FT) & SPECIE NAME & SPECIE COUNT & TOTAL COUNT \\
\hline 1 & $1640-4560$ & - & Barren & 0 \\
\hline 2 & 4620 & Eponides cf. eshira & 1 & 1 \\
\hline 3 & $4680-4820$ & - & Barren & 0 \\
\hline 4 & 5040 & Floriluscostiferum & 1 & 1 \\
\hline 5 & $5100-6340$ & - & Barren & 0 \\
\hline 6 & 6400 & $\begin{array}{c}\text { Arenaceous indeterminate, } \\
\text { Trochammina sp. }\end{array}$ & $\begin{array}{l}1 \\
1\end{array}$ & 2 \\
\hline 7 & $6520-7300$ & - & Barren & 0 \\
\hline 8 & 7440 & Arenaceous indeterminate & 1 & 1 \\
\hline 9 & 7620 & Foraminiferal indeterminate & 1 & 1 \\
\hline 10 & 7800 & $\begin{array}{l}\text { Planktic indeterminate } \\
\text { Arenaceous indeterminate }\end{array}$ & $\begin{array}{l}1 \\
1\end{array}$ & 2 \\
\hline 11 & $7860-9560$ & - & Barren & 0 \\
\hline 12 & 9620 & Planktic indeterminate & 1 & 1 \\
\hline 13 & 9680 & Florilusatlanticus & 1 & 1 \\
\hline 14 & 9740 & - & Barren & 0 \\
\hline 15 & 9800 & Nonionellatugidus & 1 & 1 \\
\hline 16 & $9920-10760$ & - & Barren & 0 \\
\hline 17 & 10900 & Poritextulariapanamensis & 1 & 1 \\
\hline 18 & $11040-11100$ & - & Barren & 0 \\
\hline \multirow[t]{8}{*}{19} & 11160 & Quinqueloculinarhodiensis, & 1 & 10 \\
\hline & & Spiroplecatamminawrightii & 2 & \\
\hline & & Cyclammina minima & 1 & \\
\hline & & Floriluscostiferum & 1 & \\
\hline & & Florilusatlanticus & 1 & \\
\hline & & Nonionellaturgidus & 2 & \\
\hline & & Cancris oblongus & 1 & \\
\hline & & Nonioncentrosulcatum & 1 & \\
\hline 20 & $11280-11580$ & - & Barren & 0 \\
\hline 21 & 11640 & Arenaceous indeterminate & 2 & 2 \\
\hline \multirow[t]{2}{*}{22} & 11760 & Spiroplectamminawrightii & 1 & 2 \\
\hline & & Alveolophragmiumcrassum & 1 & \\
\hline
\end{tabular}

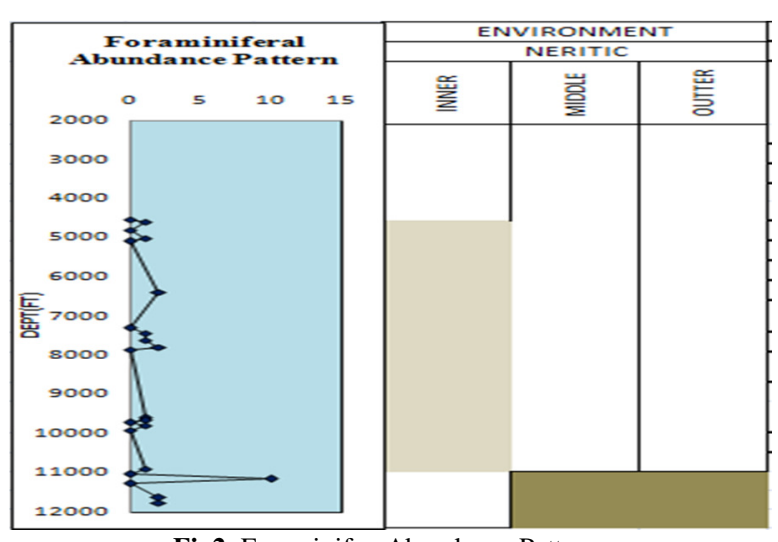

Fig2: ForaminiferaAbundance Pattern

Paleoenvironment: Foraminifera

Micropaleontological characteristics was used to enhanced the deductions of two varying depositional environments over the analyzed interval of the well, which are Continental to Marginal Marine setting and Proximal to Distal Inner Neritic environment based on the abundance and diversity of certain ecological groups of foraminifera and lithological characteristics of the sediments.

These deductions were based primarily on benthic foraminiferal assemblage,their abundance and diversity. The presence or absence of planktic foraminifera also helped in deciphering open ocean environments.

Details of the paleoenvironmental interpretations:

Continental to Marginal Marine setting:This environment is interpreted for paleoenvironmental zone which covers from $1640 \mathrm{ft}$ to $11,100 \mathrm{ft}$ of the well.The non-recovery to rare foraminiferal species recorded within this interval suggests that the environment is unsuitable for the colonization of foraminiferal species probably as a result of high energy of the environment. A probable Continental environment to Marginal marine environments is suggested. 
Proximal to Distal Inner Neritic: This is a subdivision of marine environment that lies within $0-50 \mathrm{~m}$ on the continental shelf .This environment is interpreted for paleoenvironmental zone which covers from $11,160 \mathrm{ft}$ to $11,760 \mathrm{ft}$ of the well.The presence of few foraminiferal species consisting of rare benthic foraminiferal species and absence of planktics foraminiferal species indicate deposition in shallow water, suggests sediments deposition was fluctuating between proximal to distal Inner Neritic

Conclusion: The foraminifer's analysis of Oligocene to Early Miocene sediments of Greater Ughelli Depobelt Niger Delta Basin was used to determine the paleoenvironment of the studied section. The sample intervals analyzed yielded about twenty six (26) foraminiferal species, most of the species recorded are calcareous and arenaceous benthic foraminiferal species while planktic foraminiferal species are generally scarce in the well. The presence of few foraminiferal species consisting of rare benthic foraminiferal and scarcity of planktics foraminiferal species indicating deposition in a shallow water, suggesting that the sediments deposition is fluctuating between proximal to distal Inner Neritic.

Acknowledgement: The authors are grateful to Nigerian Petroleum Development Company(NPDC) Beninand Earth Probe Ltd Lagos for their assistance in this research.

\section{REFERENCES}

Allmon, WD (1993). In Defense of Paleontology. Geotimes. November 1993, p. 1-5.

Avbovbo, AA (1978). Tertiary lithostratigraphy of Niger Delta: American Association of Petroleum Geologists Bulletin, Vol. 62, p. 295306.

Bolli, HM and Saunders, JB(1985). Oligocene to Holocene low latitude planktic foraminifera. In, HM. Bolli, JB. Saunders and K. Perch-Nielsen (Eds.), Plankton Stratigraphy. Cambridge University Press, p. 155-262.

Chiaghanam, OI; Nwozor, KK; Chiadikobi, $\mathrm{KC}$;Omoboriowo, AO; Soronnadi-Ononiwu, CG; Onuba, LN; Ofoma, AE,(2013). Lithofacies, Palynology and Paleoenvironmental Study of Early Campanian to Mid-Maastrichtian Deposits of Udi and Environs. Int. Journ. of Sci. and Tech, Vol. 2, p. 14-16.

Doust, H and Omatsola, E(1990). Niger Delta. In: Edwards, J. D. and Santogrossi, P. A. (Eds.), Divergent/passive Margin Basins. American Association of Petroleum Geologists Bulletin, Vol. 48, p. 201-238.

Fadiya, SL (1999). Foraminifera and Calcareous nannofossils biostratigraphy and well log sequence stratigraphic analysis of Opolo-5 and Opolo-6 wells, Niger Delta. Unpublished M.Sc Thesis, Department of Geology, Obafemi Awolowo University, IleIfe. Abstract published in AAPG Bulletin 82(11) p. 2162.

Haq, B;Hardenbol, J and Vail PR (1987). "The Chronology of Fluctuating Sea Level since the Triassic", J. Science, Vol.235, p. 1156-1167.

Kennet, J and Srinivasan MS(1983). Neogene Planktonic Foraminifera. Hutchinson Ross, New York.

Kulke, H(1995). Nigeria, in, Kulke, H., ed., Regional Petroleum Geology of the World. Part II: Africa, America, Australia and Antarctica: Berlin, GebrüderBorntraeger, p. 143-172.

Nwozor, KR; Omudu, MI; Ozumba, BM;Egbuachor, CJ; Onwuemesi, AG;Anike, OL (2013). Quantitative evidence of secondary mechanisms of overpressure generation: Insights from parts of Onshore Niger Delta, Nigeria, petr. Techn. Dev. Jour., Vol. 3(1), p. 64-83.

Short and Stauble, (1967). Outline of Geology of the Niger Delta. AAPG Bull 51; Vol .51,( 5) p.761 779.

Stacher, P(1995). Present understanding of the Niger Delta hydrocarbon habitat, In: Oti, M. N. and Postma, G. (Eds.), Geology of Deltas: Rotterdam, A. A. Balkema, p. 257-267.

Weber and Daukoru,(1975). Petroleum Geological aspects of the Niger Delta $9^{\text {th }}$ World Petroleum Congress, Tokyo, Proc., Vol. 2, P. 209-221.

Whiteman, AJ(1982). Nigeria: Its Petroleum Geology, Resources and Potential. Graham and Trotman, London. p. 1-394. 